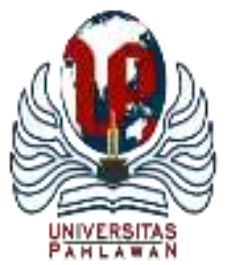

Edukatif : Jurnal Ilmu Pendidikan Volume 3 Nomor 6 Tahun 2021 Halm 4289 - 4300

EDUKATIF: JURNAL ILMU PENDIDIKAN

Research \& Learning in Education

https://edukatif.org/index.php/edukatif/index

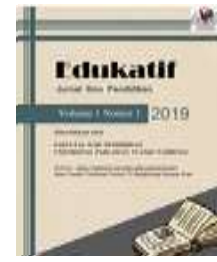

\title{
Analisis Tindak Tutur Ilokusi pada Caption Instagram Tokopedia serta Pemanfaatannya sebagai Bahan Ajar Teks Persuasi di Sekolah Menengah Pertama
}

\author{
Rahmayani $^{1 凶}$, Dewi Herlina Sugiarti ${ }^{2}$, Uah Maspuroh ${ }^{3}$ \\ Universitas Singaperbangsa Karawang, Indonesia ${ }^{1,2,3}$ \\ E-mail : $1710631080126 @$ student.unsika.ac.id ${ }^{1}$, dewi.herlina@fkip.unsika.ac.id ${ }^{2}$, \\ uah.maspuroh@fkip.unsika.ac.id ${ }^{3}$
}

\begin{abstract}
Abstrak
Penelitian ini dilatarbelakangi karena kurangnya pemanfaatan caption atau keterangan tulisan pada unggahan foto dan video dalam akun media sosial Instagram, terutama dalam caption akun media sosial Instagram @ tokopedia. Tujuan dari penelitian ini adalah untuk mendeskripsikan bentuk tindak tutur ilokusi dan fungsi tindak tutur ilokusi yang ada pada caption Instagram @tokopedia dengan edisi 'Waktu Indonesia Belanja' serta pemanfatannya sebagai bahan ajar teks persuasi di Sekolah Menengah Pertama. Adapun metode yang digunakan dalam penelitian ini yaitu deskriptif kualitatif. Sumber data dalam penelitian ini adalah caption dalam akun media sosial Instagram @ tokopedia. Dalam teknik pengumpulan data, dilakukan dengan metode simak dengan teknik catat. Dalam tahapan teknik analisis data, dilakukan secara tahap pertama mengambil data, mencatat tuturan, lalu mengkategorikan data berdasarkan tindak tutur ilokusi, setelah itu menarik kesimpulan hasil analisis tersebut. Kemudian hasil analisis dari penelitian ini ditemukan adanya lima bentuk tindak tutur ilokusi, diantaranya, asertif, direktif, komisif, ekspresif, dan deklaratif. Berdasarkan hasil analisis penelitian ini yang didapat dari 32 caption pada akun Instagram @ tokopedia, ditemukan sebanyak 85 tuturan.

Kata Kunci: Pragmatik, Tindak Tutur, Teks Persuasi.
\end{abstract}

\section{Abstract}

This research is motivated by the lack of use of captions or written descriptions on photo and video uploads on Instagram social media accounts, especially in the captions of the Instagram @ tokopedia social media account. The purpose of this study is to describe the form of illocutionary speech acts and the function of illocutionary speech acts in the Instagram caption @ tokopedia with the edition of 'Indonesian Shopping Time' and their use as teaching materials for persuasive texts in Junior High Schools. The method used in this research is descriptive qualitative. The data source in this study is the caption in the Instagram @ tokopedia social media account. In the data collection technique, it is carried out by the method of observing with the note-taking technique. In the data analysis technique stage, the first stage is taking data, recording speech, then categorizing the data based on illocutionary speech acts, after that drawing conclusions from the results of the analysis. Then the results of the analysis of this study found that there were five forms of illocutionary speech acts, including, assertive, directive, commissive, expressive, and declarative. Based on the results of this research analysis obtained from 32 captions on the @ tokopedia Instagram account, found as many as 85 utterances.

Keywords: Pragmatics, Speech Act, Persuasion Text.

Copyright (c) 2021 Rahmayani, Dewi Herlina Sugiarti, Uah Maspuroh

$\triangle$ Corresponding author

Email : 1710631080126@student.unsika.ac.id

DOI : https://doi.org/10.31004/edukatif.v3i6.1310

ISSN 2656-8063 (Media Cetak)

ISSN 2656-8071 (Media Online) 
4290 Analisis Tindak Tutur Ilokusi pada Caption Instagram Tokopedia serta Pemanfaatannya sebagai Bahan Ajar Teks Persuasi di Sekolah Menengah Pertama - Rahmayani, Dewi Herlina Sugiarti, Uah Maspuroh DOI: https://doi.org/10.31004/edukatif.v3i6.1310

\section{PENDAHULUAN}

Media sosial sangat berpengaruh terhadap perkembangan zaman saat ini, dengan kecanggihan teknologi, begitu banyak aplikasi media sosial yang bisa digunakan oleh masyarakat luas. Terutama dalam media sosial Instagram, pada media sosial Instagram, pengguna Instagram akan disuguhkan dengan layanan unggah foto, video yang dilengkapi tulisan pada unggahan tersebut. Menurut Bambang (Difika, 2016) Instagram adalah sebuah aplikasi dari smartphone yang khusus untuk media sosial yang merupakan salah satu media digital yang mempunyai fungsi hampir sama dengan twitter, namun perbedaannya terletak pada pengambilan foto dalam bentuk atau tempat untuk berbagi informasi terhadap penggunanya. Dalam tulisan atau caption di Instagram, masyarakat bisa mendapatkan berbagai informasi lengkap terkait unggahan foto dan video tersebut. Dalam hal ini, tentunya caption bisa dikategorikan termasuk tuturan dalam media sosial. Dalam cabang ilmu linguistik, tuturan terdapat dalam kajian pragmatik. Pragmatik adalah telaah mengenai segala aspek makna yang tidak tercakup dalam teori semantik, atau dengan perkataan lain, membahas segala aspek makna ucapan yang tidak dapat dijelaskan secara tuntas oleh referensi langsung pada kondisi-kondisi kebenaran kalimat yang diucapkan. Telaah mengenai bagaimana cara kita melakukan sesuatu dengan memanfaatkan kalimat-kalimat adalah telaah mengenai tindak ujar (speech acts). Tindak tutur (speech act) merupakan segala wujud tindak kebahasaan yang dilahirkan atas konteks yang menyelimuti penutur. Menurut Yule (Wibowo, 2018) mendefinisikan tindak tutur as the action perfomed by a speaker with an utterance. Tindak tutur dapat dideskripsikan sebagai suatu tindakan untuk meminta, memerintahkan, mempertanyakan, atau menginformasikan. Tindak tutur dibagi menjadi tiga yaitu tindak lokusi, tindak ilokusi, dan tindak perlokusi. Tindak tutur juga merupakan bagian dalam komunikasi bahasa. Sebagai makhluk sosial, tentu manusia membutuhkan alat komunikasi dalam berbahasa menyampaikan pesan, dan pesan tersebut bisa kita ketahui melalui tuturan yang diucapkan oleh manusia. Bahasa merupakan sistem lambang berupa bunyi bersifat arbitrer yang digunakan oleh suatu masyarakat tutur untuk bekerja sama, berkomunikasi dan mengidentifikasi diri (Chaer, 2009).

Manusia merupakan makhluk sosial yang hidup berkelompok saling membutuhkan satu sama lain (Inah, 2013). Manusia adalah mahkluk yang berpikir. Manusia akan mengucapkan apa yang dipikirkannya melalui bahasa. Dengan bahasa, manusia bisa mengungkapkan sebuah ide, gagasan, pikiran, konsep, dan juga perasaannya. Manusia juga dapat menerima informasi, berita, atau pesan-pesan melalui bahasa. Bahasa berfungsi sebagai alat komunikasi, implementasi penggunaan bahasa dalam masyarakat dapat terlihat pada media-media komunikasi, baik itu media elektronik seperti televisi dan radio, media massa online (internet), maupun pada media cetak seperti koran, dan majalah. Media yang paling diminati oleh masyarakat di zaman modern ini adalah media online (internet). Menurut Kaplan dan Haenlein (Purbohastuti, 2017) media sosial adalah media online, dengan para penggunanya bisa dengan mudah berpatisipasi, berbagi, dan menciptakan isi meliputi blog, jejaring sosial, wiki, forum dan dunia virtual. Media online membutuhkan perangkat berbasis komputer dan koneksi internet untuk mencari dan menerima informasi (Saputri, 2016). Keberadaan smartphone di lingkungan anak pada zaman sekarang ini sangat sulit memisahkan kehidupan manusia dengan smartphone (Sobry, 2017). Ketika menggunakan gawai, tentu masyarakat akan menambahkan aplikasiaplikasi media sosial untuk gawainya. Media sosial merupakan media yang berisi aplikasi untuk menciptakan sebuah isi atau pesan dengan cara berbagi menggunakan media internet seperti blog, twitter, facebook, dan Instagram (Azizah et al., n.d.). Aplikasi merupakan suatu perangkat komputer yang siap pakai bagi user (Melani et al., 2018). Aplikasi-aplikasi yang telah disebutkan tadi merupakan aplikasi yang banyak digunakan masyarakat untuk mencari seputar informasi apapun. Pada penelitian ini, peneliti memilih aplikasi media sosial Instagram untuk menganalisis sebuah tuturan.

Penelitian ini akan difokuskan terhadap satu media sosial saja, yaitu media sosial Instagram. Instagram merupakan media sosial yang banyak penggunanya. Instagram juga merupakan media sosial yang sangat 
4291 Analisis Tindak Tutur Ilokusi pada Caption Instagram Tokopedia serta Pemanfaatannya sebagai Bahan Ajar Teks Persuasi di Sekolah Menengah Pertama - Rahmayani, Dewi Herlina Sugiarti, Uah Maspuroh DOI: https://doi.org/10.31004/edukatif.v3i6.1310

populer saat ini. Instagram masuk dalam kategori komunitas online yang dibentuk melalui media internet, dimana komunitas tersebut dipilih berdasarkan kesadaran diri mereka sendiri dan tidak terbatas oleh ruang dan waktu. (Witanti, 2017). Alasan dipilihnya Instagram, karena Instagram juga suatu tempat berbagi foto dan video yang berisikan caption yang berbentuk tulisan yang dapat mengakibatkan terjadinya adanya sebuah tindak tutur. Menurut Kontenesia (Amaliah, 2019) mengatakan bahwa caption adalah tulisan singkat yang menerangkan kegiatan dalam foto atau gambar dan dituliskan di bawah foto atau gambar tersebut. Dalam hal ini, peneliti menggunakan caption yang ada dalam keterangan unggahan foto atau video di media sosial Instagram. Dalam caption Instagram bisa ditemukan dalam keterangan unggahan foto dan video. Selain itu juga, dalam caption Instagram terdapat tindak tutur ilokusi. Salah satu akun Instagram yang menggunakan bahasa untuk meningkatkan kualitas kegiatanya yaitu akun Instagram @ tokopedia. Dalam penelitian ini, akun Instagram @ tokopedia dipilih karena pada akun Instagram @tokopedia aktif dalam mengunggah berupa foto dan video yang disertakan caption yang memiliki maksud tertentu. Maksud-maksud tertentu tersebut disampaikan secara tertulis pada keterangan unggahan foto atau video tersebut, yang mana tulisan tersebut mengandung tuturan.

Penelitian ini akan difokuskan pada caption yang terdapat pada unggahan foto dan video di Instagram @ tokopedia, karena caption yang disajikan di keterangan setiap unggahan foto dan video pada akun media sosial Instagram @tokopedia mengandung unsur bujukan yang memiliki daya tarik yang unik sehingga penonton pun ikut berpikir maksud dan tujuan dari caption tersebut, selain itu juga, pengemasan yang kreatif pada setiap kalimat pada caption Instagram @ tokopedia membuat penikmat Instagram tidak bosan ketika caption itu muncul bersamaan dengan unggahan foto atau videonya. Pada caption Instagram @ tokopedia, terdapat tindak tutur yang mengandung pesan tertentu. Pesan disampaikan secara langsung dan tidak langsung. Sesuai penelitian ini, pada caption unggahan foto atau video pada akun Instagram @ tokopedia edisi 'Waktu Indonesia Belanja', peneliti juga menemukan adanya pesan-pesan yang ingin disampaikan penulis melalui tulisan yang terdapat pada caption yang ada pada akun Instagram @ tokopedia edisi 'Waktu Indonesia Belanja'. Dalam penelitian ini, peneliti akan memaparkan makna yang terkandung pada caption di akun Instagram @ tokopedia edisi ‘Waktu Indonesia Belanja' dengan pendekatan tindak tutur.

Tindak tutur terdapat tiga jenis tindak tutur yaitu, tindak lokusi, tindak ilokusi, dan tindak perlokusi. Menurut Wijana (Sari, 2012) tindak tutur lokusi adalah tindak tutur untuk menyatakan sesuatu, jelas tertuju pada suatu permasalahan. Menurut Wijana (Sari, 2012) tindak tutur ilokusi adalah tindak tutur yang fungsinya selain untuk mengatakan sesuatu, tindak ini juga digunakan untuk melakukan sesuatu. Sedangkan tindak tutur perlokusi menurut Wijana (Sari, 2012) tindak perlokusi adalah tindak tutur yang seringkali memiliki pengaruh terhadap yang mendengarkan tuturan tersebut. Menurut Searle (Yuliana et al., 2013) menyatakan bahwa dalam praktik penggunaan bahasa terdapat setidaknya tiga macam tindak tutur. Ketiga macam tindak tutur adalah sebagai berikut. Pertama, tindak tutur lokusi, yaitu tindak tutur dengan kata, frasa, dan kalimat sesuai dengan makna yang dikandung oleh kata, frasa, dan kalimat itu. Kedua, tindak tutur ilokusi, yaitu tindak tutur untuk melakukan sesuatu dengan maksud dan fungsi tertentu pula. Ketiga, tindak tutur perlokusi, yaitu tindak tutur yang menumbuhkan pengaruh (effect) kepada mitra tutur.

Dalam penelitian ini, hanya satu jenis tindak tutur yang dipilih, karena dalam caption tentu mengandung pesan yang disampaikan secara langsung dan tidak langsung, maka dari itu tindak tutur ilokusi dipilih karena tindak tutur ilokusi memaparkan informasi yang digunakan untuk melakukan sesuatu, mengandung arti makna tersendiri. Pada penelitian ini akan difokuskan hanya pada satu edisi yaitu edisi Tokopedia yang bertema 'Waktu Indonesia Belanja' saja, karena pada tema tersebut Tokopedia menampilkan caption yang berisi tuturan seolah-olah pengguna Instagram ikut berpikir dan merasakan apa yang sedang dibicarakan. Tokopedia memilih untuk memakai tema 'Waktu Indonesia Belanja' yang berarti waktunya masyarakat Indonesia berbelanja dengan sepuasnya di Tokopedia setiap tanggal 25 sampai akhir bulan. 
4292 Analisis Tindak Tutur Ilokusi pada Caption Instagram Tokopedia serta Pemanfaatannya sebagai Bahan Ajar Teks Persuasi di Sekolah Menengah Pertama - Rahmayani, Dewi Herlina Sugiarti, Uah Maspuroh DOI: https://doi.org/10.31004/edukatif.v3i6.1310

Penelitian ini juga mengambil sebanyak tiga puluh dua unggahan foto, video, dan pamflet yang berisi caption dari akun Instagram @ tokopedia dengan rentang waktu bulan November 2020 sampai dengan Januari 2021.

Pemanfaatan penelitian ini dapat digunakan dalam pembelajaran sebagai bahan ajar. Pembelajaran adalah proses interaksi peserta didik dengan pendidik dan sumber belajar pada suatu lingkungan. Dalam pembelajaran tentu membutuhkan bahan ajar sebagai materi yang akan diberikan kepada siswa. Menurut Mulyasa (Suwardika, 2017) mengemukakan bahan ajar merupakan suatu pesan pembelajaran yang bersifat khusus maupun umum yang dapat dimanfaatkan sebagai kepentingan dalam pembelajaran. Bahan ajar tersebut dapat berupa tertulis seperti hand out, buku, modul, lembar kerja mahasiswa, brosur, leaflet, wallchart, maupun bahan tidak tertulis seperti video/film, VCD, radio, kaset, CD interaktif berbasis computer dan internet (Arsanti, 2018). Penelitian ini dapat digunakan sebagai bahan ajar pada materi teks persuasi pada jenjang Sekolah Menengah Pertama (SMP) yang disesuaikan dengan kompetensi dasar dan silabus kurikulum 2013. Menurut Kosasih (Rahma \& Pristiwati, 2019), mengatakan teks persuasi adalah teks tentang pernyataan-pernyataan yang berisi ajakan atau bujukan untuk mendorong peserta didik mengikuti keinginan dari penulis. Bahan ajar tersebut yakni materi mengenai teks persuasi pada caption Instagram @ tokopedia edisi 'Waktu Indonesia Belanja'. Berdasarkan uraian yang telah dipaparkan, tuturan yang terdapat pada caption pada akun Instagram @tokopedia edisi 'Waktu Indonesia Belanja' bisa dijadikan acuan siswa dalam membuat teks persuasi, dan siswa bisa mencari tahu bagaimana membuat kalimat untuk membuat teks persuasi.

\section{METODE PENELITIAN}

Metode yang digunakan dalam penelitian ini yaitu deskriptif kualitatif. Menurut Cresswell (Khusnah, 2015) menyatakan bahwa penelitian kualitatif sebagai suatu gambaran kompleks, meneliti kata-kata, laporan terinci dari pandangan responden dan melakukan studi pada situasi yang dialami. Penelitian kualitatif dilakukan pada kondisi alamiah dan bersifat penemuan. Menurut Sudaryanto, Sumarwati, dan Suryanto (Sikana, 2020), metode deskriptif digunakan untuk mengumpulkan, mengklasifikasikan serta memaparkan terkait informasi pada keadaan yang sedang berlangsung dengan media berupa kata ataupun gambar dan informasi yang dijabarkan bukan berupa angka. Menurut Bogdan dan Taylor (Moleong, 2017) mendefinisikan metodologi kualitatif sebagai prosedur penelitian yang menghasilkan data deskriptif berupa kata-kata tertulis atau lisan dari orang-orang dan perilaku yang dapat diamati. Sedangkan menurut Denzin dan Lincoln (Moleong, 2017) menyatakan bahwa penelitian kualitatif adalah penelitian yang menggunakan latar alamiah, dengan maksud menafsirkan fenomena yang terjadi dan dilakukan dengan jalan melibatkan berbagai metode yang ada. Dari beberapa definisi tersebut, dapat disimpulkan bahwa metode deskriptif kualitatif yaitu penelitian yang menghasilkan data deskriptif berupa kata-kata tertulis atau lisan dari objek yang diamati serta menggunakan latar alalmiah, menafsirkan fenomena yang terjadi dan dilakukan dengan melibatkan berbagai metode yang ada. Dalam penelitian ini informasi yang dipaparkan terdapat pada tindak tutur dalam caption akun Instagram @ tokopedia edisi 'Waktu Indonesia Belanja'.

Dalam penelitian kualitatif, yang menjadi instrumen atau alat penelitian adalah peneliti itu sendiri. Oleh karena itu peneliti sebagai instrumen juga harus "divalidasi" seberapa jauh peneliti kualitatif siap melakukan penelitian yang selanjutnya terjun ke lapangan. Validasi terhadap peneliti sebagai instrumen meliputi validasi terhadap pemahaman metode penelitian kualitatif, penguasaan wawasan terhadap bidang yang diteliti, kesiapan peneliti untuk memasuki obyek penelitian, baik secara akademik maupun logistiknya. Yang melakukan validasi adalah peneliti sendiri, melalui evaluasi diri seberapa jauh pemahaman terhadap metode kualitatif, penguasaan teori dan wawasan terhadap bidang yang diteliti, serta kesiapan dan bekal memasuki lapangan. (Sugiyono, 2015). Dengan demikian instrumen penelitian dalam penelitian kualitatif yaitu peneliti itu sendiri, peneliti yang mencari data penelitian, memahami, mengolah data, hingga hasil yang didapat 
sendiri. Dalam proses penelitian tentunya peneliti memerlukan alat untuk menunjang terlaksananya sebuah penelitian, alat yang dimaksudkan yaitu alat bantu selama penelitian berlangsung, instrumen yang diperlukan dalam penelitian ini diantaranya laptop, gawai, caption akun Instagram @ tokopedia, dan alat tulis.

Menurut Lofland dan Lofland (Moleong, 2017) sumber data utama dalam penelitian kualitatif ialah kata-kata, dan tindakan, selebihnya adalah data tambahan seperti dokumen dan lain-lain. Data yang diperoleh dari penelitian ini yaitu transkip tuturan berupa kalimat atau paragraf yang ada pada caption akun Instagram @ tokopedia edisi 'Waktu Indonesia Belanja'. Peneliti memilih tuturan mana saja yang termasuk ke dalam tindak tutur ilokusi. Peneliti memilih tiga puluh dua unggahan foto dan video yang diambil dari akun Instagram @tokopedia edisi 'Waktu Indonesia Belanja' dikarenakan tiga puluh dua unggahan foto dan video pada akun Instagram @ tokopedia itu memiliki tulisan yang cukup banyak sehingga memungkinkan banyak tuturan yang akan diteliti serta tiga puluh dua unggahan foto dan video tersebut bertepatan dengan program Tokopedia 'Waktu Indonesia Belanja'. Sumber data dari penelitian ini yaitu caption pada unggahan foto dan video yang diunggah di Instagram @ tokopedia pada bulan November 2020 hingga Januari 2021.

Dalam penelitian ini, teknik pengumpulan data dilakukan dengan metode simak dengan teknik catat. Dalam tahapan teknik analisis data, dilakukan secara tahap pertama mengambil data, mencatat tuturan, lalu mengkategorikan data berdasarkan tindak tutur ilokusi, setelah itu menarik kesimpulan hasil analisis tersebut. Kemudian hasil analisis dari penelitian ini ditemukan adanya lima bentuk tindak tutur ilokusi, diantaranya, asertif, direktif, komisif, ekspresif, dan deklaratif.

\section{HASIL DAN PEMBAHASAN PENELITIAN}

Berdasarkan data dari penelitian yang telah dilakukan, peneliti menggunakan 32 caption dari unggahan foto dan video yang berasal dari akun media sosial Instagram @ tokopedia pada bulan November 2020 sampai Januari 2021. Dari 32 caption tersebut, didapatkan hasil sebanyak 85 tuturan caption yang termasuk dalam tindak tutur ilokusi (meliputi asertif, direktif, ekspresif, komisif, dan deklaratif).

Adapun jumlah keseluruhan data yang termasuk ke dalam bentuk tindak tutur ilokusi sebanyak 85 data yang meliputi, bentuk tuturan asertif terdapat sebanyak 34 data, bentuk tuturan direktif terdapat sebanyak 41 data, bentuk tuturan komisif terdapat sebanyak 5 data, bentuk tuturan ekspresif terdapat sebanyak 4 data, bentuk tuturan deklaratif terdapat sebanyak 1 data. Adapun data yang termasuk ke dalam fungsi pada tindak tutur ilokusi, diantaranya, dalam tindak tutur ilokusi dengan bentuk asertif terdapat 7 fungsi asertif, dari data pada caption akun Instagram @ tokopedia hanya terdapat 4 fungsi, yaitu menyatakan terdapat 4 data, memberitahukan terdapat 25, menyarankan terdapat 3 data, dan melaporkan terdapat 1 data. Pada fungsi direktif, sesuai data yang diperoleh dari caption akun Instagram @tokopedia, terdapat 4 fungsi, yaitu memerintah terdapat 24 data, meminta sebanyak 4 data, menganjurkan 11 data, dan menasihatkan terdapat 2 data. Pada fungsi komisif, sesuai data yang diperoleh dari caption akun Instagram @ tokopedia, terdapat hanya 1 fungsi, yaitu menawarkan terdapat 4 data. Pada fungsi ekspresif, sesuai data yang diperoleh dari caption akun Instagram @ tokopedia, terdapat 2 fungsi, yaitu mengucapkan terima kasih sebanyak 3 data, dan menyalahkan sebanyak 1 data. Pada fungsi deklaratif, sesuai data yang diperoleh dari caption akun Instagram @ tokopedia, terdapat 1 fungsi, yaitu menentukan 1 data.

\section{A. Data Tindak Tutur Ilokusi}

1. Tindak Tutur Asertif

\section{Data 1}

Tanggal: 19 November 2020

Tiap kali mimin dengerin lagunya kepala auto angguk-angguk sesuai iramanya. Kamu gitu juga gak?

Sudah siap juga kan untuk lihat penampilan idola favorit kamu? 
4294 Analisis Tindak Tutur Ilokusi pada Caption Instagram Tokopedia serta Pemanfaatannya sebagai Bahan Ajar Teks Persuasi di Sekolah Menengah Pertama - Rahmayani, Dewi Herlina Sugiarti, Uah Maspuroh DOI: https://doi.org/10.31004/edukatif.v3i6.1310

Download aplikasi tokopedia sekarang!

\#tokopediawib \#tokopediapromo \#promo \#waktuindonesiabelanja

Sumber: tuturan tersebut ditulis oleh seorang admin Instagram @ tokopedia pada 19 november 2020. Caption tersebut bermaksud melaporkan ungkapan seseorang yang ketika mendengar lagu Tokopedia WIB otomatis menggerakkan kepalanya senada dengan iringan nada lagu tersebut, sekaligus memerintah pengguna Instagram untuk mengunduh aplikasi Tokopedia.

Tabel 1. Data 1

\begin{tabular}{llll}
\hline No. & Tuturan & Bentuk & Fungsi \\
\hline 1. & $\begin{array}{l}\text { Tiap kali mimin dengerin lagunya kepala } \\
\text { auto angguk-angguk sesuai iramanya. }\end{array}$ & Asertif & Melaporkan \\
\hline 2. & Download aplikasi tokopedia sekarang! & Direktif & Memerintah \\
\hline
\end{tabular}

Tuturan data 1 mengungkapkan tentang ungkapan seseorang yang setiap mendengarkan nada terkait soundtrack Tokopedia WIB seseorang tersebut dengan sendirinya menganggukkan kepala sembari mengikuti nada lagu tersebut, dan seolah bertanya kepada semuanya tentang kesiapan menyambut artis yang akan hadir dalam Tokopedia WIB.

Tuturan data 1 terdapat dua tuturan yang termasuk dalam tindak tutur ilokusi dengan kategori asertif dan direktif. Dalam caption data 1, yang termasuk ke dalam kategori ilokusi asertif yaitu 'Tiap kali mimin dengerin lagunya kepala auto angguk-angguk sesuai iramanya.' Tuturan tersebut termasuk dalam bentuk asertif yang memiliki fungsi untuk melaporkan, karena, tuturan tersebut bermaksud melaporkan bahwa ketika seseorang tersebut mendengarkan lagu soundtrack Tokopedia WIB dengan otomatis anggota tubuh bagian kepala seseorang tersebut mengangguk mengikuti sesuai irama. Adapun tuturan lainnya dari data 1 yang termasuk dalam tindak tutur ilokusi dengan kategori ilokusi direktif, yaitu 'Download aplikasi tokopedia sekarang!'. Tuturan tersebut temasuk dalam ilokusi direktif yang memiliki fungsi memerintah, karena tuturan tersebut bermaksud memberikan efek bahwa kepada para pengguna Instagram untuk segera mengunduh aplikasi Tokopedia saat itu juga.

\section{Tindak Tutur Direktif}

\section{Data 16}

Tanggal: 26 Desember 2020

Sudah nonton serunya \#TokopediaWIBTV SHOW tadi malam? Jangan lupa pilih artis favoritmu untuk tampil selanjutnya!

Kamu bisa vote di aplikasi Tokopedia 1x sehari sampai tanggal 31 Desember 2020. Jangan lupa ajak temanteman kamu untuk ikutan vote yuk

Vote sekarang

klik link di bio

tokopedia.link/voteWIBTV

Sumber: Caption tersebut ditulis oleh seorang admin akun media sosial Instagram @ tokopedia pada 26 Desember 2020. Caption tersebut bermaksud menginformasikan untuk memilih artis idola untuk penampilan di Tokopedia WIB TV Show, pengguna Instagram bisa memilih dengan cara voting di aplikasi Tokopedia satu kali dalam sehari sampai tanggal 31 Desember 2020. 

Ajar Teks Persuasi di Sekolah Menengah Pertama - Rahmayani, Dewi Herlina Sugiarti, Uah Maspuroh DOI: https://doi.org/10.31004/edukatif.v3i6.1310

Tabel 2. Data 2

\begin{tabular}{llll}
\hline No. & Tuturan & Bentuk & Fungsi \\
\hline 1. & $\begin{array}{l}\text { Sudah nonton serunya \#TokopediaWIBTV } \\
\text { SHOW tadi malam? Jangan lupa pilih artis } \\
\text { favoritmu untuk tampil selanjutnya! }\end{array}$ & Direktif & Memerintah \\
\hline 2. & $\begin{array}{l}\text { Kamu bisa vote di aplikasi Tokopedia 1x } \\
\text { sehari sampai tanggal 31 Desember 2020. }\end{array}$ & Direktif & Memerintah \\
\hline
\end{tabular}

Dalam data 16, terdapat 2 tuturan caption yang termasuk dalam tindak tutur ilokusi dengan kategori bentuk direktif. Dalam data nomor 1, tuturan tersebut masuk dalam tindak tutur ilokusi dengan kategori bentuk direktif, karena memberikan efek kepada mitra tuturnya, serta memiliki fungsi memerintah untuk memilih artis favorit para pengguna Instagram untuk bisa tampil di acara Tokopedia WIB TV Show selanjutnya. Dalam data nomor 2, tuturan tersebut masuk dalam tindak tutur ilokusi dengan kategori bentuk direktif, karena memberikan efek kepada mitra tuturnya, serta memiliki fungsi memerintah, karena diperintah untuk memilih dengan cara voting di aplikasi Tokopedia, serta diperintah mengajak teman-teman lainnya untuk voting di aplikasi Tokopedia juga.

\section{Tindak Tutur Komisif}

\section{Data 7}

Tanggal: 25 November 2020

Terima kasih atas antusiasme kalian untuk \#TokopediaWIB TV Show malam ini! Part mana yang paling kalian suka?

Masih ada kejutan lagi nih, mulai MALAM INI kamu bisa pilih artis favoritmu yang belum pernah tampil di \#TokopediaWIB TV Show untuk tampil selanjutnya!

Ingat yaa, kamu bisa vote 1x sehari di aplikasi Tokopedia sampai 30 November! Ajak teman-temanmu juga untuk ikutan voting yaa.

VOTE SEKARANG

klik link bio

tokopedia.link/voteWIBTV

Sumber: Caption tersebut ditulis oleh seorang admin akun media sosial Instagram @ tokopedia pada 25 November 2020. Caption tersebut bermaksud memberikan ucapan terima kasih kepada para penonton Tokopedia WIB TV Show, lalu Tokopedia memberikan kejutan lainnya dan mengajak pengguna Instagram untuk memilih artis favorit sekali dalam sehari di aplikasi Tokopedia sampai 30 November.

Tabel 3. Data 3

\begin{tabular}{llll}
\hline No. & Tuturan & Bentuk & Fungsi \\
\hline 1. & $\begin{array}{l}\text { Terima kasih atas antusiasme kalian untuk } \\
\text { \#TokopediaWIB TV Show malam ini! Part } \\
\text { mana yang paling kalian suka? }\end{array}$ & $\begin{array}{l}\text { Ekspresif } \\
\text { kasih }\end{array}$ & \\
& & & Menawananan \\
\hline 2. $\quad \begin{array}{l}\text { Masih ada kejutan lagi nih, mulai MALAM } \\
\text { INI kamu bisa pilih artis favoritmu yang } \\
\text { belum pernah tampil di \#TokopediaWIB } \\
\text { TV Show untuk tampil selanjutnya! }\end{array}$ & & \\
&
\end{tabular}


Dalam data 7 terdapat 4 tuturan caption yang termasuk dalam tindak tutur ilokusi dengan kategori ekspresif, komisif, dan direktif. Dalam data nomor 1, tuturan tersebut masuk dalam tindak tutur ilokusi dengan bentuk ekspresif, karena mengungkap perasaan penutur terhadap suasana yang tersirat, tuturan tersebut juga memiliki fungsi mengucapkan terima kasih, karena berterima kasih kepada antusiasme para penonton yang menonton acara Tokopedia WIB TV Show. Dalam data nomor 2, tuturan tersebut masuk dalam tindak tutur ilokusi dengan bentuk komisif, karena seolah menawarkan sesuatu, yang memiliki fungsi menawarkan, karena memberikan penawaran untuk bebas memilih artis favorit yang pernah tampil di Tokopedia WIB TV Show, hal itu ditunjukkan dalam rangka untuk menghadirkan bintang tamu yang akan hadir di acara yang akan datang. Dalam data nomor 3, tuturan tersebut masuk dalam tindak tutur ilokusi dengan bentuk direktif, karena memberikan efek kepada mitra tutur, yang memiliki fungsi menasihatkan, karena terdapat perkataan yang mengingatkan bahwa bisa memilik satu kali sehari di aplikasi Tokopedia sampai 30 November. Dalam data nomor 4, tuturan tersebut masuk dalam tindak tutur ilokusi dengan bentuk direktif, karena memberikan efek kepada mitra tutur, yang memiliki fungsi meminta, karena seolah meminta untuk mengajak teman-teman lainnya untuk turut serta mengikuti voting tersebut, lalu mengharuskan untuk memilih (vote) saat itu juga.

\section{Tindak Tutur Ekspresif}

\section{Data 4}

Tanggal: 25 November 2020

Andai mimin bisa mempercepat waktu... Tapi gapapa, Rose, Jennie, Jisoo, dan Lisa setia nungguin kita kok! Jangan lewatkan keseruan \#TokopediaWIB TV Show malam ini bersama BLACKPINK!

\section{MALAM INI!}

Rabu, 25 November 2020

20:00 - 21:30

NET TV, SCTV, Indosiar, dan Youtube Tokopedia

Set Reminder mu biar ga kelewatan!

tkp.me/wibtvshownov

Download atau update versi terbaru aplikasi Tokopedia ya! Pastikan kamu juga sudah subscribe Youtube Tokopedia.

Selain penampilan spesial dari BLACKPINK, akan ada banyak promo dan kejutan yang bisa kamu dapatkan! Cek infonya di tokopedia link/wibtvigp atau klik link di BIO.

\#TokopediaxBlackpink \#tokopedia \#blackpink \#tokopediawibtvshow \#wibtvshow \#blink

Sumber: Caption tersebut ditulis oleh seorang admin akun media sosial Instagram @ tokopedia pada 25 November 2020. Caption tersebut bermaksud menginformasikan terkait jadwal Tokopedia WIB TV Show dengan bintang tamu BLACKPINK akan tayang malam pada 25 November 2020, namun, sebelumnya admin seperti menyayangkan bahwa seharusnya bisa mempercepat waktu penayangan. Untuk itu diingatkan untuk menyetel waktu pengingat agar tidak ketinggalan waktu penayangan tersebut. Dalam caption tersebut juga diperintah untuk mengunduh aplikasi Tokopedia dan memperbarui aplikasi tersebut, lalu pastikan juga sudah mengikuti Tokopedia di kanal Youtubenya. Dalam caption tersebut juga diinformasikan bahwa selain penampilan spesial dari BLACKPINK, akan ada kejutan dan promo lainnya yang bisa didapatkan, untuk mengetahui hal tersebut, pengguna Instagram diimbau untuk mengunjungi laman web Tokopedia yang tersedia di bio Instagram @ tokopedia. 
4297 Analisis Tindak Tutur Ilokusi pada Caption Instagram Tokopedia serta Pemanfaatannya sebagai Bahan Ajar Teks Persuasi di Sekolah Menengah Pertama - Rahmayani, Dewi Herlina Sugiarti, Uah Maspuroh DOI: https://doi.org/10.31004/edukatif.v3i6.1310

Tabel 4. Data 4

\begin{tabular}{|c|c|c|c|}
\hline No. & Tuturan & Bentuk & Fungsi \\
\hline 1. & $\begin{array}{l}\text { Andai mimin bisa mempercepat waktu... } \\
\text { Tapi gapapa, Rose, Jennie, Jisoo, dan Lisa } \\
\text { setia nungguin kita kok! }\end{array}$ & Ekspresif & Menyalahkan \\
\hline 2. & $\begin{array}{l}\text { Jangan lewatkan keseruan \#TokopediaWIB } \\
\text { TV Show malam ini bersama } \\
\text { BLACKPINK! } \\
\text { MALAM INI! } \\
\text { Rabu, } 25 \text { November } 2020 \\
\text { 20:00 - 21:30 } \\
\text { NET TV, SCTV, Indosiar, dan Youtube } \\
\text { Tokopedia }\end{array}$ & Asertif & Memberitahukan \\
\hline 3. & Set Reminder mu biar ga kelewatan! & Direktif & Memerintah \\
\hline 4. & $\begin{array}{l}\text { Download atau update versi terbaru aplikasi } \\
\text { Tokopedia ya! Pastikan kamu juga sudah } \\
\text { subscribe Youtube Tokopedia }\end{array}$ & Direktif & Memerintah \\
\hline 5. & $\begin{array}{l}\text { Selain penampilan spesial dari } \\
\text { BLACKPINK, akan ada banyak promo dan } \\
\text { kejutan yang bisa kamu dapatkan! }\end{array}$ & Asertif & Memberitahukan \\
\hline 6. & $\begin{array}{l}\text { Cek infonya di tokopedia link/wibtvigp atau } \\
\text { klik link di BIO. }\end{array}$ & Direktif & Menganjurkan \\
\hline
\end{tabular}

Tuturan caption tersebut mengungkap informasi terkait jadwal penayangan BLACKPINK dalam acara Tokopedia WIB TV Show, namun seorang admin yang menuliskan caption tersebut menyayangkan bahwa pihaknya tidak bisa memajukan jam penayangan BLACKPINK. Lalu mengingatkan kepada pengguna Instagram untuk menyetel waktu pengingat, mengimbau juga untuk mengunduh aplikasi Tokopedia dan memastikan untuk mengikuti Tokopedia di kanal Youtube juga. Informasi selanjutnya adalah selain penampilan BLACKPINK, ada juga promo dan kejutan menarik lainnya yang bisa didapatkan, untuk mengetahui informasi tersebut bisa mengunjungi laman web Tokopedia atau klik link laman tersebut di bio Instagram @ tokopedia.

Tuturan caption yang ada dalam data 4, ditemukan ada 6 yang termasuk dalam tindak ilokusi dengan kategori bentuk asertif, direktif, dan ekspresif, 2 asertif, 3 direktif, dan 1 ekspresif. Dalam data 4 nomor 1, tuturan pada caption tersebut termasuk ke dalam tindak tutur ilokusi dengan bentuk ekspresif, karena tuturan tersebut meluapkan perasaan seolah menyayangkan tidak bisa memajukan waktu penayangan BLACKPINK, serta tuturan memiliki fungsi menyalahkan, karena menyayangkan tindakannya yang tak bisa memajukan jam tayang BLACPINK. Dalam data 4 nomor 2, tuturan pada caption tersebut termasuk ke dalam tindak tutur ilokusi dengan bentuk asertif, karena menjelaskan dengan apa adanya bahwa jadwal penayangan acara Tokopedia WIB TV Show yang dibintangi oleh BLACKPINK, tuturan tersebut juga memiliki fungsi yaitu menyatakan, bahwa jadwal tayang acara Tokopedia WIB TV Show yang dihadiri BLACKPINK dilaksanakan pada 25 November 2020, pukul 20:00 - 21:30 yang disiarkan di NET TV, SCTV, Indosiar, dan Youtube Tokopedia. Dalam data 4 nomor 3, tuturan pada caption tersebut termasuk dalam tindak tutur ilokusi dengan bentuk direktif, karena membuat pengaruh agar mitra tutur melakukan tindakan, bahwa untuk menyetel waktu pengingat. Dalam data 4 nomor 4 , tuturan pada caption tersebut termasuk dalam tindak tutur ilokusi dengan bentuk direktif, karena memerintahkan bahwa untuk pengguna Instagram diimbau untuk mengunduh aplikasi Tokopedia, tuturan tersebut juga memiliki fungsi yaitu memerintah, karena tuturan caption tersebut 
memerintah pengguna Instagram untuk mengunduh aplikasi Tokopedia dan memperbaruinya, serta memerintah untuk mengikuti Tokopedia di kanal Youtube. Dalam data 4 nomor 5, tuturan termasuk ke dalam tindak tutur ilokusi dengan bentuk asertif, karena menjelaskan sesuatu dengan apa adanya bahwa selain penampilan spesial dari BLACKPINK, Tokopedia menghadirkan beragam promo dan kejutan yang bisa didapat, tuturan tersebut juga memiliki fungsi yaitu memberitahukan, karena menginformasikan bahwa selain BLACKPINK yang turut memeriahkan acara Tokopedia WIB TV Show, ada promo dan kejutan lainnya yang akan hadir di Tokopedia WIB TV Show. Dalam data 4 nomor 6 termasuk ke dalam tindak tutur ilokusi dengan bentuk direktif, karena tuturannya membuat pengaruh agar mitra tutur melakukan tindakan, pengguna Instagram diimbau untuk mengecek informasi lebih lanjut melalui link Tokopedia yang disediakan, tuturan caption tersebut juga memiliki fungsi menganjurkan, karena pengguna Instagram dianjurkan untuk mengecek informasi terkait acara Tokopedia WIB TV Show dengan penampilan spesial BLACKPINK melalui link yang sudah disediakan pada bio Instagram @ tokopedia.

\section{Tindak Tutur Deklaratif}

\section{Data 22}

Tanggal: 22 Januari 2021

Minto yakin ini salah satu promo favorit kamu jadi harusnya tau dong jawabannya

Follow IG Tokopedia dan menangkan XIAOMI REDMI 8!!

Cara ikutannya:

1. Follow @ tokopedua dan LIKE postingan ini.

2. Jawab pertanyaan dan kasih tau alasanmu kenapa harus dapetin hadiahnya.

3. Tambahkan hashtag \#TokopehadiahBO serta tag 2 temen kamu di kolom komentar.

4. 1 (satu) pemenang yang terpilih dengan alasan paling menarik akan mendapatkan XIAOMI REDMI 8.

5. Pemenang akan diumumkan tanggal 5 Februari 2021 di IG Story.

\#giveawayIndonesia \#giveawayolshop \#giveawayid \#giveawayindo \#giveaway \#kuis \#giveaway \#promo \# giveawayhp.

Sumber: Caption tersebut ditulis oleh seorang admin akun media sosial Instagram @ tokopedia pada 22 Januari 2021. Caption tersebut bermaksud menginformasikan bahwa untuk mendapatkan Xiaomi Redmi 8 harus mengikuti langkah-langkah secara berurutan sesuai yang disajikan.

Tabel 5. Data 5

\begin{tabular}{|c|c|c|c|}
\hline No. & Tuturan & Bentuk & Fungsi \\
\hline 1. & $\begin{array}{l}\text { Minto yakin ini salah satu promo favorit } \\
\text { kamu jadi harusnya tau dong jawabannya }\end{array}$ & Deklaratif & Menentukan \\
\hline 2. & $\begin{array}{l}\text { Follow IG Tokopedia dan menangkan } \\
\text { XIAOMI REDMI 8!! }\end{array}$ & Direktif & Memerintah \\
\hline 3. & $\begin{array}{l}\text { Cara ikutannya: } \\
\text { 1. Follow @ tokopedua dan LIKE } \\
\text { postingan ini. } \\
\text { 2. Jawab pertanyaan dan kasih tau } \\
\text { alasanmu kenapa harus dapetin } \\
\text { hadiahnya. } \\
\text { 3. Tambahkan hashtag } \\
\text { \#TokopehadiahBO serta tag } 2 \\
\text { temen kamu di kolom komentar. } \\
\text { 4. } 1 \text { (satu) pemenang yang terpilih } \\
\text { dengan alasan paling menarik akan }\end{array}$ & Asertif & Memberitahukan \\
\hline
\end{tabular}


4299 Analisis Tindak Tutur Ilokusi pada Caption Instagram Tokopedia serta Pemanfaatannya sebagai Bahan Ajar Teks Persuasi di Sekolah Menengah Pertama - Rahmayani, Dewi Herlina Sugiarti, Uah Maspuroh DOI: https://doi.org/10.31004/edukatif.v3i6.1310

mendapatkan XIAOMI REDMI 8.

5. Pemenang akan diumumkan

tanggal 5 Februari 2021 di IG

Story.

Dalam data 22 terdapat 3 tuturan caption yang termasuk dalam tindak tutur ilokusi, 1 dengan bentuk asertif, 1 dengan bentuk direktif, dan 1 dengan bentuk deklaratif. Dalam data nomor 1 , tuturan tersebut termasuk dalam tindak tutur ilokusi dengan kategori bentuk deklaratif, karena tuturan dilakukan petutur dengan maksud menciptakan suatu hal, yang memiliki fungsi menentukan, bahwa seorang admin Instagram Tokopedia sudah yakin menentukan bahwa promo yang disajikan memang favorit para pengguna Instagram. Dalam data nomor 2, tuturan tersebut termasuk dalam tindak tutur ilokusi dengan kategori bentuk direktif, karena memberikan pengaruh kepada mitra tutur untuk melakukan tindakan, yang memiliki fungsi memerintah, untuk segera mengikuti akun Instagram Tokopedia agar bisa memenangkan hadiah Xiaomi Redmi 8. Dalam data nomor 3, tuturan tersebut termasuk dalam tindak tutur ilokusi dengan kategori bentuk asertif, karena menjelaskan sesuai apa yang ada, yang memiliki fungsi memberitahukan bahwa untuk bisa mengikuti kuis tersebut, maka harus mengikuti bagaimana langkah-langkah yang sudah dijelaskan.

\section{KESIMPULAN}

Berdasarkan hasil penelitian dari pembahasan mengenai Analisis Tindak tutur Ilokusi pada Caption Instagram Tokopedia Edisi 'Waktu Indonesia Belanja' Serta Pemanfaatannya sebagai Bahan Ajar Teks Persuasi di Sekolah Menengah Pertama, maka dapat disimpulkan bahwa ditemukannya banyak tuturan dari caption akun Instagram @ tokopedia menggunakan bentuk dan jenis tindak tutur asertif serta bentuk dan jenis tindak tutur direktif. Setiap perusahaan tentu memiliki cara tersendiri dalam memasarkan produknya. Ketika itu diungkapkan melalui tulisan, pasti memiliki keunikan dan makna masing-masing yang mana tuturan tersebut untuk menarik para pembeli.

Dalam penelitian ini, ditemukan dari caption akun Instagram @ tokopedia banyak menggunakan tindak tutur ilokusi dengan bentuk asertif yang terbagi atas beberapa fungsi di dalamnya, diantaranya menyatakan, memberitahukan, menyarankan, dan melaporkan. Selain itu juga, dari caption akun Instagram @ tokopedia banyak menggunakan tindak tutur ilokusi dengan bentuk direktif yang terbagi atas beberapa fungsi di dalamnya, diantaranya memerintah, meminta, menganjurkan, dan menasihatkan.

\section{UCAPAN TERIMA KASIH}

Peneliti menghaturkan ucapan terima kasih kepada Allah SWT, sehingga penulis dapat menyelesaikan penelitian ini, khususnya peneliti juga mengucapkan terima kasih kepada Ibu Dewi Herlina Sugiarti, S.Pd., M.Pd., selaku Dosen Pembimbing 1, dan Ibu Uah Maspuroh, S.Pd., M.Pd., selaku Dosen Pembimbing 2. Ucapan terima kasih lainnya peneliti ucapkan kepada kedua orang tua yang telah terlibat dalam memberikan dukungan dan do'a, serta semua pihak yang tidak bisa disebutkan satu per satu yang terlibat dalam penelitian ini.

\section{DAFTAR PUSTAKA}

Amaliah, L. R. (2019). Ketidakefektifan Kalimat Pada Caption Instagram Mahasiswa Fakultas Pertanian Universitas Winaya Mukti. Literasi, Jurnal Ilmiah Pend. Bahasa, Sastra Indonesia Dan Daerah, Vol. 9(2), 69. 
4300 Analisis Tindak Tutur Ilokusi pada Caption Instagram Tokopedia serta Pemanfaatannya sebagai Bahan Ajar Teks Persuasi di Sekolah Menengah Pertama - Rahmayani, Dewi Herlina Sugiarti, Uah Maspuroh DOI: https://doi.org/10.31004/edukatif.v3i6.1310

Arsanti, M. (2018). Pengembangan Bahan Ajar Mata Kuliah Penulisan Kreatif Bermuatan Nilai-Nilai Pendidikan Karakter Religius Bagi Mahasiswa Prodi Pbsi, Fkip, Unissula. Jurnal Kredo, Vol 1(2), 74.

Azizah, A., Mustika, I., \& Primndhika, R. B. (N.D.). Analisis Tindak Tutur Caption Dalam Instagram Ridwan Kamil. Parole (Jurnal Pendidikan Bahasa Dan Sastra Indonesia), Vol 3(3), 230.

Chaer, A. (2009). Psikolinguistik. Pt. Rineka Cipta.

Difika, F. (2016). Dakwah Melalui Instagram (Studi Analisis Materi Dakwah Dalam Instagram Yusuf Mansur, Felix Siauw, Aa Gym, Arifin Ilham). Semarang: Universitas Islam Negeri Walisongo Semarang.

Inah, E. N. (2013). Peranan Komunikasi Dalam Pendidikan. Jurnal Al-Ta'dib, Vol. 6(1), 176.

Khusnah, M. (2015). Strategi Kepala Madrasah Dalam Membangun Komitmen Guru Dalam Organisasi (Studi Kasus Di Madrasah Ibtidaiyah Negeri Beji, Pasuruan). Malang: Universitas Islam Negeri Maulana Malik Ibrahim Malang.

Melani, Siregar, H. F., \& Siregar, Y. H. (2018). Perancangan Aplikasi Komik Hadist Berbasis Multimedia. Jurnal Teknologi Informasi, Vol. 2(2), 113.

Moleong, L. (2017). Metodologi Penelitian Kualitatif. Pt. Remaja Rosdakarya Bandung.

Purbohastuti, A. W. (2017). Efektivitas Media Sosial Sebagai Media Promosi. Jurna. Tirtayasa Ekonomika, Vol 12(2), 212.

Rahma, U. L., \& Pristiwati, R. (2019). Keterampilan Menyajikan Teks Persuasi Melalui Model Scaffolding Dengan Media Kartu Cerita Lingkungan Kita (Kartalita). Jurnal Profesi Keguruan, Vol 5(2), 181.

Saputri, R. N. (2016). Pembingkaian Isu Pengesahan Perppu Kebiri Melalui Pemberitaan Di Portal Berita Online (Analisis Framing Pada Portal Berita Online Republika.Co.Id Dan Detik.Com Periode 27 Mei14 Juni 2016). Malang: Universitas Muhammadiyah.

Sari, F. (2012). Tindak Tutur Dan Fungsi Tuturan Ekspresif Dalam Acara Galau Nite Di Metro Tv: Suatu Kajian Pragmatik. Repository Unair, Vol. 1(2), 3.

Sikana, A. (2020). Tindak Tutur Ilokusi Pada Iklan Fair And Lovely Di Televisi. Imajeri: Jurnal Pendidikan Bahasa Dan Sastra Indonesia, Vol. 3(1), 94.

Sobry, M. G. (2017). Peran Smartphone Terhadap Pertumbuhan Dan Perkembangan Anak. Jurnal Penelitian Guru Indonesia, Vol 2(2), 26.

Sugiyono. (2015). Metode Penelitian Kuantitatif Kualitatif Dan R\&D. Alfabeta Cv.

Suwardika, A. (2017). Pengembangan Bahan Ajar Berbentuk Bagan Berbasis Tematik Pada Tema 7 Subtema 3 Kelas Iii Sekolah Dasar. Repository Unja.

Wibowo, S. E. (2018). Etnopragmatik Bingkai Budaya Jawa. Cv. Sarnu Untung.

Witanti, P. (2017). Motif Penggunaan Media Sosial Instagram Di Kalangan Remaja. Jurnal Communication, $\operatorname{Viii}(1), 52$.

Yuliana, R., Rohmadi, M., \& Suhita, R. (2013). Daya Pragmatik Tindak Tutur Guru Dalam Pembelajaran Bahasa Indonesia Pada Siswa Sekolah Menengah Pertama. Basastra Jurnal Penelitian Bahasa, Sastra Indonesia Dan Pengajarannya, 2(1), 1-14. 